\title{
Assessing Key Business-related Indicators for Smart Cities: Case of Tbilisi City
}

\author{
Tamar Khakhishvili, PhD Student \\ School of Business Administration, Grigol Robakidze University, Georgia
}

Doi:10.19044/esj.2020.v16n22p15 ～URL:http://dx.doi.org/10.19044/esj.2020.v16n22p15

\begin{abstract}
"Smart City" concept has become more popular in recent years. High interest is derived from the need to implement smart solutions and address the challenges associated with rapid population growth in urban areas. This paper focuses on assessing key business-related indicators that measure Tbilisi performance towards the achievement of smart city solutions. Since there are hundreds of smart city indicators in the world, this paper only focuses on researching business environment (i.e., Smart Economy out of the six (6) smart city characteristics ${ }^{5}$ ). The methodology used in this study was based on both theoretical and practical approach. Detailed analysis of scientific papers, especially World Bank (Doing Business) and World Economic Forum (Global Competitiveness Index) reports, made it possible to identify key businessrelated indicators. In-depth analysis revealed five (5) indicators ${ }^{6}$. At the next stage, comparative analysis of Tbilisi and Stockholm was conducted to assess growth rates for each identified ones. Using statistical and historical data study, research results provided the opportunity to elaborate assessment framework that proposed the methodology for assessing the above mentioned indicators. After the analysis (according to the methodology of elaborated assessment framework), the research shows that Tbilisi only fulfills two (2) business-related indicators out of the five (5) identified.
\end{abstract}

Keywords: Smart city, indicators, city performance, Tbilisi, Stockholm

\section{Introduction}

The concept of "Smart City" has become more popular since 2000s. This fact is related to the rapid growth of cities as population started moving from rural to industrial areas (Ritchie \& Roser, 2018). Presently, more than

${ }^{5}$ There are six characteristics of smart cities (Giffinger \& Gudrun, 2009): Smart Economy, Smart Government, Smart living, Smart People, Smart Environment, and Smart Mobility.

${ }^{6}$ Note that this paper detects key indicators that are major and only business-related. The research does not include all smart city indicators. 
$50 \%$ of the world's population resides in urban areas, while the same figure in 1950 was $30 \%$. As a result of this trend, by 2050, more than two-thirds of the world's population is projected to live in the cities (United Nations, 2018). In parallel with rapid development processes, frequent discussions on smart cities in scientific literature as well as in the policy reports and municipality strategies have gained popularity. This fact is related to the thoughts that smart cities have adequate forces to illuminate solutions for addressing complications of urbanization (Monzon, 2015). In the paper "Smart Cities Concept and Challenges: Bases for the Assessment of Smart City Projects", Andres Monzon (2015) describes that the main goal of smart city initiatives is to introduce solutions for improving quality of life and ensuring sustainability of the city. Other researches also show that smart cities have demonstrated potential to tackle economic, social, and environmental concerns (Hajikhani, 2020). Arash Hajikhani calls urbanization "contemporary challenge" and stresses that smart cities can provide cities with novel and effective approaches for better governance.

Tbilisi - capital of Georgia - has often challenged other cities with creative and innovative initiatives introduced in the city in the last 20 years (Forbes Georgia, 2018; Narmania \& Shaburishvili, 2017). One of the World Bank blogs (Hoornweg, 2011) warmly characterizes smart city as welcoming, inclusive, and an open city that is being forthright with citizens. However, it should be noted that the abovementioned description in some way is associated with the City of Tbilisi (Georgia, 2012). Despite implementing important initiatives in relation to urban development, livability improvement, introduction of sustainable transport and environmental solutions, sources from academic literature prove that there are huge differences between sustainable and smart cities, and the cities are challenged to satisfy Key Performance Indicators (KPIs) for being truly smart (Ahvenniemi et al., 2017). Therefore, this paper goes deeper into one of the indicators (Economy) and investigates key features that form strong entrepreneurial climate in the cities. The assessment is carried out so as to evaluate the business-related performance of Tbilisi. To achieve this objective, key indicators are revealed and comparative analysis of Tbilisi and Stockholm is carried out. In spite of huge differences in the size of economy and the level of development, the City of Stockholm has been selected for the purpose of comparison with its growth tendency. This is because of two main reasons; firstly, the capital of Sweden has been recently declared as Smart City of 2019 (Government Europa, 2019) at the Smart City Expo World Congress in Barcelona and satisfies all relevant criteria. Secondly, the size of the population and the area of these two cities 
are not too different from each other ${ }^{7}$. These facts give possibility to represent accurate comparison because the research is focused on percentage increase and not on the exact figures.

\section{Methods}

The objective of the study is to assess key business-related indicators that measure Tbilisi performance towards the achievement of smart city solutions. Therefore, the paper introduces a holistic framework to gather, analyze, and compare data.

The proposed methodology included two (2) stages which were outlined in nine steps:

First Stage: (1) Analyzing six (6) characteristics of Smart Cities (Giffinger \& Gudrun, 2009) with the main focus on Smart Economy; (2) Understanding dimensions of regulatory environment for Georgia according to World Bank Doing Business Report (World Bank Group, 2020); (3) Evaluating different pillars of Global Competitiveness Index framework (World Economic Forum, n.d.); (4) Determining five (5) key business-related indicators.

Second Stage: (5) Formulating assessment framework and defining methodology for verification of indicators; (6) Detailed reviewing of Tbilisi data for several years in relation to each selected indicator and calculating growth rates; (7) Being a Smart City 2019 winner, selecting Stockholm for modeling, and gathering data of Stockholm in relation to identified indicators; (8) Conducting comparative analysis of the data of Tbilisi and Stockholm; (9) Verifying the indicators based on the proposed methodology and assessing Tbilisi performance.

\section{Theoretical Framework}

Notwithstanding the fact that smart cities became popular in XXI century, the history of the term starts from 1990s (Hajikhani, 2020). Nevertheless, at this time, it was only related to information and communications technology (ICT) based on infrastructure development.

However, the concept has been explored over time and in-depth analysis showed that smart city is multifaceted and relates to interdisciplinary studies. The contemporary studies (Vienna University of Technology, n.d.) also highlighted that the term "smart cities" has changed its meaning and has moved to the next phase (called "Smart City 4.0"). At this stage, technologies and infrastructure are no longer the main characteristics of the term. This implies that new areas of focus have been disclosed.

${ }^{7}$ Only the Municipality of Stockholm is selected for the research (not the whole urban or metropolitan area). 
Smart city model ensures that cities develop economically, livability is improved, and the environment is protected at the same time (Bibri, 2018). It encourages innovations, good governance, local economic development (LED), entrepreneurship, and environmentally friendly transport (World Economic Forum, 2014). Furthermore, Khushboo and Hall (2020) explained that at the beginning of 2000s, smart city development was focused on technological advancement. This means that it was more related to tech companies. Caragliu, Del Bo and Nijkamp (2009) argued that this approach had limited effect and did not have significant impact on a large size of population. Currently, the concept focuses more on city development and technological progress is just a tool to improve sustainable transport, solve traffic problems, support entrepreneurship, and tackle other challenging issues.

There are several different ideas on how to define smart cities. One of the simplest definitions (Department for Business, Innovation and Skills, 2013) explains that smart city is more of a process rather than a result. In this process, citizen engagement is developed and sustainable infrastructure, social capital, and digital technologies are ensured. All these make cities more livable, connective, and resilient. The same idea is also shared by Khushboo Gupta and Ralph P. Hall (2020). The researchers also opined that smart cities must be considered as "the means" to achieve better quality of life rather than "an end" objective. Another academic definition is suggested by Giffinger et al. (2007) as cited in Khushboo and Hall (2020). According to the source, smart cities are described as "well-performing modern cities built on the smart combination of endowments and activities of self-decisive, independent, and aware citizens looking to develop intelligent solutions to enhance the quality of life and services." An interesting and simple definition of smart cities is provided also by Smart Cities Council. According to the organization, smart city uses digital technologies to enhance livability, workability, and sustainability in the city (Khushboo \& Hall, 2020; Smart Cities Council, n.d.).

A journalist of Forbes known as James Ellsmoor (2019) refers to smart cities to be "Cities as Future" and links them to the Internet of Things (IoT). Another author stresses that by rendering more technology capable of communicating across platforms, IoT generates more opportunities that can help improve daily life. An interesting study is carried out by Barbara-Sanchez et al. (2019) that confirms the relationship between smart cities and entrepreneurship. Experts highlight that smart cities are the generators of new entrepreneurial initiatives. On the other hand, entrepreneurship along with innovation is considered as a major tool for economic prosperity within the city. In the article "The Smart City as an Opportunity for Entrepreneurship", authors underline that although researches have realized that smart cities are more entrepreneurial than others, detailed analysis of entrepreneurial activities 
has not been conducted (Richter, Kraus \& Syrja, 2015 as cited in Hajikhani, 2020). The above-mentioned challenge is discussed by Komninos Angelakoglou et al. (2019) as well. Authors are also concerned that in spite of the fact that there is huge interest for smart cities, the evaluation as well as the measurement of their results is rarely conducted.

In the publication "A Methodological Framework for the Selection of Key Performance Indicators to Assess Smart City Solutions", it is explained that in order to identify the efficiency of initiatives, frequent assessment is crucially important for cities. According to Komninos, Angelakoglou, and Nikos Nikolopoulos, the latter can be successfully implemented with the help of key performance indicators that ensure evaluation of the progress of smart cities.

Over time, many cities have showed their interest to see their real performance and gain a better understanding of underlying processes (Vienna University of Technology, n.d.). Several assessment frameworks are presented in different fields (energy, environment). From an academic perspective, the work of Pierpaolo Girardi and Andrea Temporelli (2016) introduce "Smartainability" approach that allows the use of qualitative and quantitative indicators and the evaluation of the level of smart cities in terms of being more sustainable in social, environmental, and economic fields.

Another good tool to assess the performance of cities is the platform of World Council of City Data (WCCD), which is a global hub possessing standardized city data. Through the Open Data Portal, WCCD unites records from over 100 member cities and enables website visitors to monitor and compare statistics up to 100 service performance and quality of life indicators (World Council of City Data, n.d.). More assessment methodologies are presented in the work of Komninos Angelakoglou et al. (2019) which introduce indicators that measure the progress of low-carbon development, indicators that focus on small and medium size communities, etc.

Besides the scientific studies in contemporary life, international organizations invest significant funds and pay vast attention to assessments of the performance of cities and nations. The next part in this paper is devoted to analysis of one of the most important and reliable publications globally. The analysis of these reports made it possible to identify key business-related indicators which afterwards measure the effectiveness of Tbilisi performance towards achieving smart city objectives.

\section{Identifying Key Business-related Indicators}

During the study, smart city characteristics have been overviewed. This has been identified by Professor Rudolf Giffinger (2010) and his colleagues at the Centre of Regional Science of Vienna University of Technology. The work of Giffinger concentrated first on identifying basic 
characteristics of national and international city rankings. In order to achieve the objective, a selected number of city rankings were analyzed. Professor Rudolf presented six "smart" characteristics: environment, economy, people, living, governance, and mobility (Giffinger \& Gudrun, 2009). Thus, the paper focuses only on Smart Economy out of the proposed six (6) fields of action. Field of Smart Economy, sometimes known as competitiveness, is broken down into 7 relevant factors: innovative spirit, entrepreneurship, economic image and trademarks, productivity, flexibility of labor market, international embeddedness, and ability to transform (Giffinger \& Gudrun, 2010).

Furthermore, another document that has been comprehensively analyzed during the study was the report of World Bank on Doing Business (World Bank Group, 2020). After summarizing economies of 190 countries and looking at domestic SMEs, Doing Business project of World Bank identified Doing Business Indicators (World Bank Group, n.d.). This includes the following: starting a business, dealing with construction permits, getting electricity, registering property, getting credit, protecting minority investors, paying taxes, trading across borders, enforcing contracts, resolving insolvency, employing workers.

Against the backdrop of economic changes derived from globalization, cities face the necessity to combine sustainable urban development and competitiveness (Vienna University of Technology, n.d.). Competitiveness seems to be the leading force for cities and nations in recent years (Porter, 2008). Due to the fact that it is important for advancing economies, it became a subject of researches for many organizations. The strongest and most sophisticated tool for assessing the competitiveness of countries is presented by World Economic Forum that introduced Global Competitiveness Index (GCI) more than 40 years ago. GCI assesses the progress of countries through evaluating different determinants of productivity (World Economic Forum, n.d.). GCI calculates index based on 12 pillars, namely: institutions, infrastructure, ICT adoption, macroeconomic stability, health, skills, product market, labor market, financial system, market size, business dynamism, and innovation capability (The Global Competitiveness Report, 2019). Since the objective of this paper is to identify and assess business-related indicators, the study focused on the components within certain pillars, precisely: $6^{\text {th }}$ pillar time to start a business, business impact of rules on FDI; $7^{\text {th }}$ pillar - cooperation in labor-employer relations, flexibility of wage determination, etc; $9^{\text {th }}$ pillar FDI and technology transfer; $10^{\text {th }}$ pillar - GDP.

After an in-depth analysis of the above-mentioned reports and studies (Smart Economy characteristics by Giffinger et al., World Bank Doing Business report, Global Competitiveness Report) and detail assessment of their components, the table below summarizes characteristics that addresses 
smart economy advancement, facilitate doing business, and improve competitiveness (Table 1).

Table 1: Characteristics identified for Smart Economy, sophisticated doing business environment, and increased competitiveness

\begin{tabular}{|c|c|c|}
\hline $\begin{array}{l}\text { Smart City Indicators: } \\
\text { Smart Economy field of } \\
\text { action }\end{array}$ & $\begin{array}{l}\text { World Bank: } \\
\text { Doing Business } \\
\text { dimensions }\end{array}$ & $\begin{array}{l}\text { Global Competitiveness Index: } \\
\text { under-pillar components } \\
\text { related to businesses }\end{array}$ \\
\hline $\begin{array}{l}\text { Innovative spirit, } \\
\text { Entrepreneurship, } \\
\text { Economic image \& } \\
\text { trademarks, } \\
\text { Productivity, } \\
\text { Flexibility of labor } \\
\text { market, } \\
\text { International } \\
\text { embeddedness, } \\
\text { Ability to transform }\end{array}$ & $\begin{array}{l}\text { Starting a business, } \\
\text { Dealing with construction } \\
\text { permits, } \\
\text { Getting electricity, } \\
\text { Registering property, } \\
\text { Getting credit, } \\
\text { Protecting minority } \\
\text { investors, } \\
\text { Paying taxes, } \\
\text { Trading across borders, } \\
\text { Enforcing contracts, } \\
\text { Resolving insolvency, } \\
\text { Employing workers }\end{array}$ & $\begin{array}{l}\text { Time to start a business, } \\
\text { Business impact of rules on FDI, } \\
\text { Cooperation in labor-employer } \\
\text { relations, } \\
\text { Flexibility of wage } \\
\text { determination, } \\
\text { FDI and technology transfer, } \\
\text { GDP }\end{array}$ \\
\hline
\end{tabular}

As described in the methodology part of this paper, the proposed study includes two (2) stages. The first stage implies analysis of the abovementioned components that makes it possible to reveal appropriate business-related indicators. The second stage is achieved via grouping components into five (5) arrays. 
Table 2: Five (5) groups identified from components of Smart Economy characteristics, World Bank Doing Business Report, and Global Competitiveness Report

\begin{tabular}{|c|c|c|c|}
\hline & $\begin{array}{l}\text { Smart City } \\
\text { Indicators: } \\
\text { Smart Economy } \\
\text { field of action }\end{array}$ & $\begin{array}{l}\text { World Bank: } \\
\text { Doing Business } \\
\text { dimensions }\end{array}$ & $\begin{array}{l}\text { Global } \\
\text { Competitiveness Index: } \\
\text { under-pillar components } \\
\text { related to business }\end{array}$ \\
\hline Group 1 & Entrepreneurship & $\begin{array}{l}\text { Starting a business; } \\
\text { Registering property }\end{array}$ & $\begin{array}{l}\text { Time to start a } \\
\text { business }\end{array}$ \\
\hline Group 2 & $\begin{array}{l}\text { Entrepreneurship; } \\
\text { productivity }\end{array}$ & $\begin{array}{l}\text { Starting a business; } \\
\text { Trading across } \\
\text { boarders; paying taxes }\end{array}$ & $\begin{array}{l}\text { GDP; } \\
\text { Time to start a } \\
\text { business }\end{array}$ \\
\hline Group 3 & $\begin{array}{l}\text { Flexibility of labor } \\
\text { market }\end{array}$ & Employing workers & $\begin{array}{l}\text { Cooperation in labor- } \\
\text { employer relations }\end{array}$ \\
\hline Group 4 & $\begin{array}{l}\text { Flexibility of labor } \\
\text { market; } \\
\text { Entrepreneurship; }\end{array}$ & $\begin{array}{l}\text { Starting a business; } \\
\text { paying taxes; } \\
\text { Employing workers }\end{array}$ & $\begin{array}{l}\text { Flexibility of wage } \\
\text { determination }\end{array}$ \\
\hline Group 5 & $\begin{array}{l}\text { International } \\
\text { embeddedness }\end{array}$ & $\begin{array}{l}\text { Protecting minority } \\
\text { investors; } \\
\text { Trading across }\end{array}$ & $\begin{array}{l}\text { business impact of } \\
\text { rules on FDI; } \\
\text { FDI and technology }\end{array}$ \\
\hline
\end{tabular}


The identified groups incorporate components that are business-related. However, each group focuses on specific business parts.

\section{Group 1}

The study identified the first group where the following components are integrated: "entrepreneurship" from Smart Economy characteristics, "starting a business" and "registering property" from World Bank Doing Business Report, and "time to start a business" from Global Competitiveness Report. All four components are likely to be united around starting entrepreneurship and underlining the importance of smart business environment for newly established businesses. Hence, the first group was named and, accordingly, the first business-related key indicator has been defined as new businesses.

\section{Group 2}

"Entrepreneurship" and "productivity" is selected from Smart Economy characteristics; "Starting a business", "trading across boarders" and "paying taxes" is selected from World Bank Doing Business Report; and "GDP" and "time to start a business" from Global Competitiveness Report have been defined as important components to be integrated in one group. These components reveal the importance of productivity and gross domestic product (GDP) for sophisticated business environment and smart cities. As a result, the second indicator was defined as Gross Domestic Product.

\section{Group 3}

Other components that have been integrated under one group are "flexibility of labor market", "employing workers", and "cooperation in laboremployer relations" from Smart Economy characteristics, World Bank Doing Business Report, and Global Competitiveness Report, respectively. The unity of these components into one group provided an opportunity for the study to highlight the role of employment for emerging cities and nations in a smart way. Employment is recognized as a key indicator of development for many countries. Hence, it holds a modest place as a key business-related indicator in this study.

\section{Group 4}

In spite of the fact that employment has been revealed as an important indicator, research shows that salaries need to be considered separately apart from employment. High employment rate does not mean too much unless average salary is growing consistently. Smart Economy characteristics, World Bank Doing Business Report, and Global Competitiveness Report are 
components that reinforce the abovementioned conclusion. "Flexibility of labor market", "entrepreneurship", "productivity", "starting a business", "paying taxes", "employing workers", and "flexibility of wage determination" are the components integrated in the fourth group known as salaries.

\section{Group 5}

The last group underlines the importance of foreign direct investments (FDI) for building smart business environment in the cities. Smart Economy field of action pointed out the "international embeddedness" component, while Doing Business Report recognized "protecting minority investors" and "trading across borders" as critical aspects. Global Competitiveness Report also pays crucial attention to FDIs which includes "business impact of rules on FDI" and "FDI and technology transfer" under its 12 pillars. Based on this, the study identified the fifth business-related indicator as foreign direct investments.

The first stage of the study identified five (5) critical business-related indicators for smart cities (new businesses, gross domestic product, employment, salary, foreign direct investments). At the second stage, assessment framework was proposed that presented measurement methodology of indicators (Table 3). The framework enabled indicators to assess Tbilisi performance towards the achievement of smart city solutions from business perspectives.

Table 3: Assessment framework for indicators' verification

\begin{tabular}{lll}
\hline $\begin{array}{l}\text { Identified Key Business- } \\
\text { related Indicators }\end{array}$ & Measurement & Monitoring \\
\hline New businesses & $\begin{array}{l}\text { Growth rate of the number } \\
\text { of newly registered } \\
\text { businesses }\end{array}$ & $\begin{array}{l}\text { Tbilisi must have the same } \\
\text { percentage of increase in the } \\
\text { number of newly registered } \\
\text { businesses as Stockholm }\end{array}$ \\
\hline Gross domestic product & GDP average growth rate & $\begin{array}{l}\text { Tbilisi must achieve the same } \\
\text { average growth rate of GDP as } \\
\text { Stockholm }\end{array}$ \\
\hline Employment & $\begin{array}{l}\text { Average number of } \\
\text { annually employed people }\end{array}$ & $\begin{array}{l}\text { Tbilisi must increase number of } \\
\text { employed people with the same } \\
\text { number annually as Stockholm } \\
\text { does }\end{array}$ \\
\hline Salary & $\begin{array}{l}\text { Growth rate of average } \\
\text { monthly salary in relation } \\
\text { to GDP growth rate }\end{array}$ & $\begin{array}{l}\text { salary of Tbilisi must equal (or be } \\
\text { close to) its growth rate of GDP }\end{array}$ \\
\hline Foreign direct investments & $\begin{array}{l}\text { Percentage of FDI growth } \\
\text { rate }\end{array}$ & $\begin{array}{l}\text { Tbilisi must achieve the same } \\
\text { percentage of increase in FDIs as } \\
\text { Stockholm }\end{array}$ \\
\hline
\end{tabular}




\section{Comparative Analysis - City of Stockholm}

The proposed assessment framework required the study of the data of Tbilisi and Stockholm, individually. It was needed to detect the percentage of growth for each identified key business-related indicator. On the other hand, the results of Stockholm were taken as basis for the assessment framework. The study selected the City of Stockholm for modeling as the capital of Sweden has been recently declared as Smart City of 2019 (Government Europa, 2019). Consequently, Stockholm is one of the leading cities in terms of innovations and constant reformer of initiatives for improving the living conditions of people and refining business environment (Wray, 2019). It is worthy to note that the size of population and area of the City of Stockholm and the City of Tbilisi are not too different from each other (Table 4). This fact made it possible for more accurate comparison to be achieved.

Table 4: Size of population and area of the City of Tbilisi and the City of Stockholm

\begin{tabular}{lll}
\hline Area & Tbilisi City & City of Stockholm \\
\hline population & $\begin{array}{l}158 \mathrm{~km}^{2} \text { urbanized area } \\
\left.\text { (total area } 502 \mathrm{~km}^{2}\right)\end{array}$ & $188 \mathrm{~km}^{2}$ \\
\hline
\end{tabular}

The first key indicator identified above is new businesses. Since all the studies stated that this indicator is crucially important to form businessfriendly environment in the city, the next part of the paper demonstrates and compares the number of newly registered businesses in Tbilisi and Stockholm (Figure 1).

Figure 1: Number of newly registered businesses in Tbilisi and Stockholm

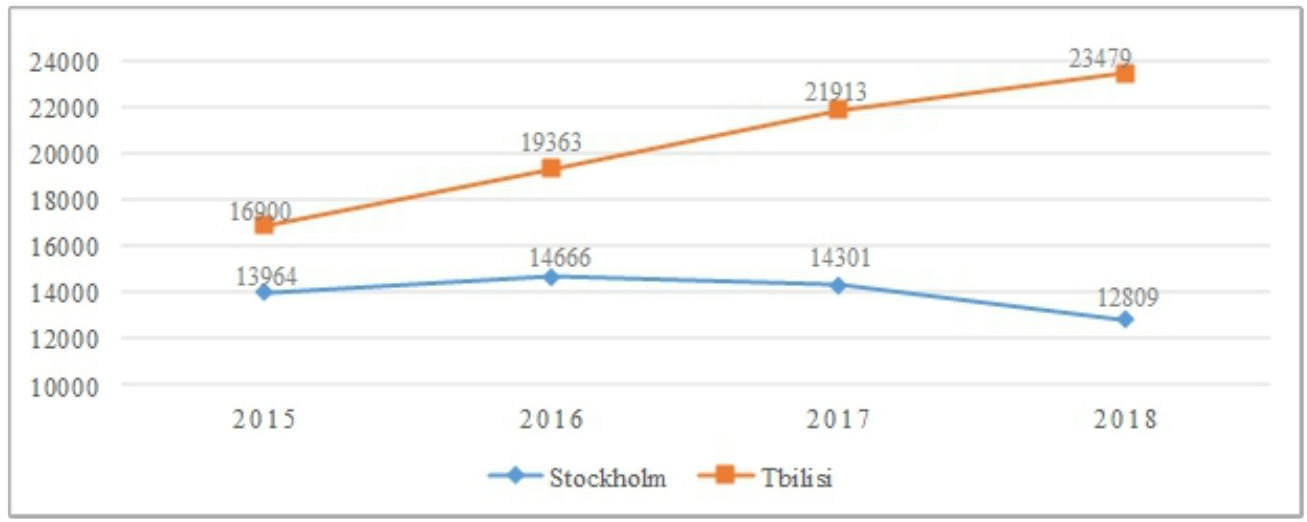

The graph shows an unexpected statistics that the number of annually registered businesses in Tbilisi is much higher than in Stockholm. This implies that in 2017-2018, Stockholm experienced the quantitative reduction of new businesses in comparison with earlier years (Statistics Sweden, n.d.), while Tbilisi has an increasing trend (National Agency of Public Registry of 
Ministry of Justice of Georgia, n.d.). The table below calculates the growth rates for each city and displays that the average growth rates for Stockholm and Tbilisi are $-2.63 \%$ and $11.63 \%$, respectively (Table 5).

Table 5: Average growth rates of newly registered businesses in the City of Stockholm and the City of Tbilisi

\begin{tabular}{lllll}
\hline & $\mathbf{2 0 1 5}$ & $\mathbf{2 0 1 6}$ & $\mathbf{2 0 1 7}$ & $\mathbf{2 0 1 8}$ \\
\hline Stockholm & & & & \\
\hline Number of registered businesses & 13964 & 14666 & 14301 & 12809 \\
\hline Growth rate (\%) & & $5,03 \%$ & $-2,49 \%$ & $-10,43 \%$ \\
Average growth rate & $\mathbf{- 2 , 6 3 \%}$ & & & \\
\hline
\end{tabular}

\begin{tabular}{lllll}
\hline Tbilisi & & & \\
\hline Number of registered businesses & 16900 & 19363 & 21913 & 23479 \\
\hline Growth rate (\%) & & $14,57 \%$ & $13,17 \%$ & $7,15 \%$ \\
Average growth rate & $\mathbf{1 1 , 6 3 \%}$ & & & \\
\hline
\end{tabular}

The second key indicator analyzed in this document is Gross domestic product of the City of Stockholm and the City of Tbilisi (Table 6).

Table 6: Gross domestic product of the City of Stockholm and the City of Tbilisi in 20152018

\begin{tabular}{lllll}
\hline & Stockholm & Tbilisi & Stockholm & Tbilisi \\
\cline { 2 - 5 } & $\begin{array}{c}\text { GDP in SEK, } \\
\text { billion }\end{array}$ & $\begin{array}{l}\text { GDP in GEL, } \\
\text { billion }\end{array}$ & GDP in USD & GDP in USD \\
\hline $\mathbf{2 0 1 5}$ & 287,7 & 17,3 & 33,8 & 7,2 \\
\hline $\mathbf{2 0 1 6}$ & 304,4 & 18,8 & 32,9 & 7,1 \\
\hline $\mathbf{2 0 1 7}$ & 320,2 & 20,9 & 38,2 & 8,1 \\
\hline $\mathbf{2 0 1 8}$ & 339,3 & 23,1 & 37,5 & 8,7 \\
\hline
\end{tabular}

Certainly, the GDP of Stockholm is much higher and cannot be compared to Tbilisi. However, in this comparison, growth rates carry more importance. The economy of the capital of Scandinavia is also huge. As a result, Figure 2 showed that Tbilisi is experiencing higher growth rate than Stockholm. The study found out that the average GDP growth rate for Stockholm was 5.65\% in 2016-2018 (Stockholm Business Region, n.d.). The same analysis showed $10.04 \%$ for Tbilisi (National Statistics Office of Georgia, n.d.).

\footnotetext{
${ }^{8}$ Exchange rates (SEK to USD and GEL to USD) are for December 31 of the corresponding years. Due to currency differences, the table shows decline in some figures in USD, while in reality GDP (in national currency) is increasing annually.
} 
Figure 2: Annual growth rate of GDP of the City of Stockholm ${ }^{9}$ and the City of Tbilisi, 2016-2018
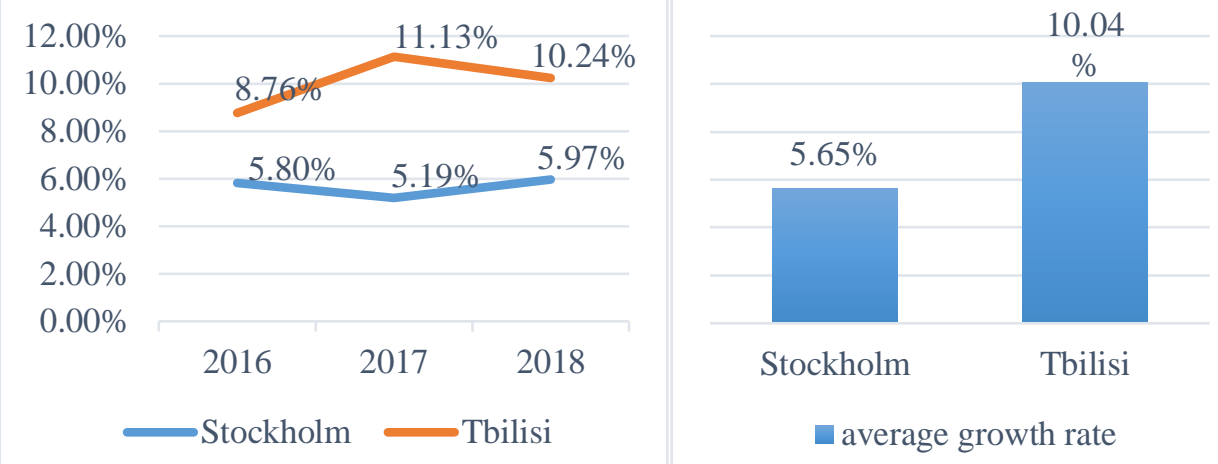

The third and fourth indicators detected in the study are related to employment and salaries. Nobody doubts the fact that the more people work, the more economic prosperity is created. Nevertheless, without salary growth, employment cannot make much difference. The table below indicates the difference between Stockholm and Tbilisi in the number of employed and unemployed people.

Table 7: Number of employed and unemployed people in the City of Stockholm and the

\begin{tabular}{lllll}
\hline & Stockholm & Tbilisi & Stockholm & Tbilisi \\
\hline & Employed & Employed & Unemployed & Unemployed \\
\hline $\mathbf{2 0 1 5}$ & 520300 & 397454 & 30868 & 116820 \\
\hline $\mathbf{2 0 1 6}$ & 529300 & 400688 & 29426 & 123273 \\
\hline $\mathbf{2 0 1 7}$ & 536600 & 384595 & 30450 & 126321 \\
\hline $\mathbf{2 0 1 8}$ & 552900 & 408153 & 29115 & 94550 \\
\hline
\end{tabular}

In the study, unemployment rates were also given close attention. Both cities calculate unemployment rate in terms of active population (in relation to population aged 15+). Unquestionably, Stockholm records magnificent statistics in these terms, and the unemployment rate never exceeds 5\% (Stockholm Business Region, n.d.). However, Tbilisi is far away from this situation. The minimum unemployment rate that Tbilisi has ever recorded is 18.81\% in 2018 (National Statistics Office of Georgia, n.d.).

\footnotetext{
${ }^{9}$ For comparative purposes, the data is analyzed for the Municipality of Stockholm (not the
} whole urban or metropolitan area). 
Figure 3: Unemployment rates of the City of Tbilisi and the City of Stockholm, 2009-2018

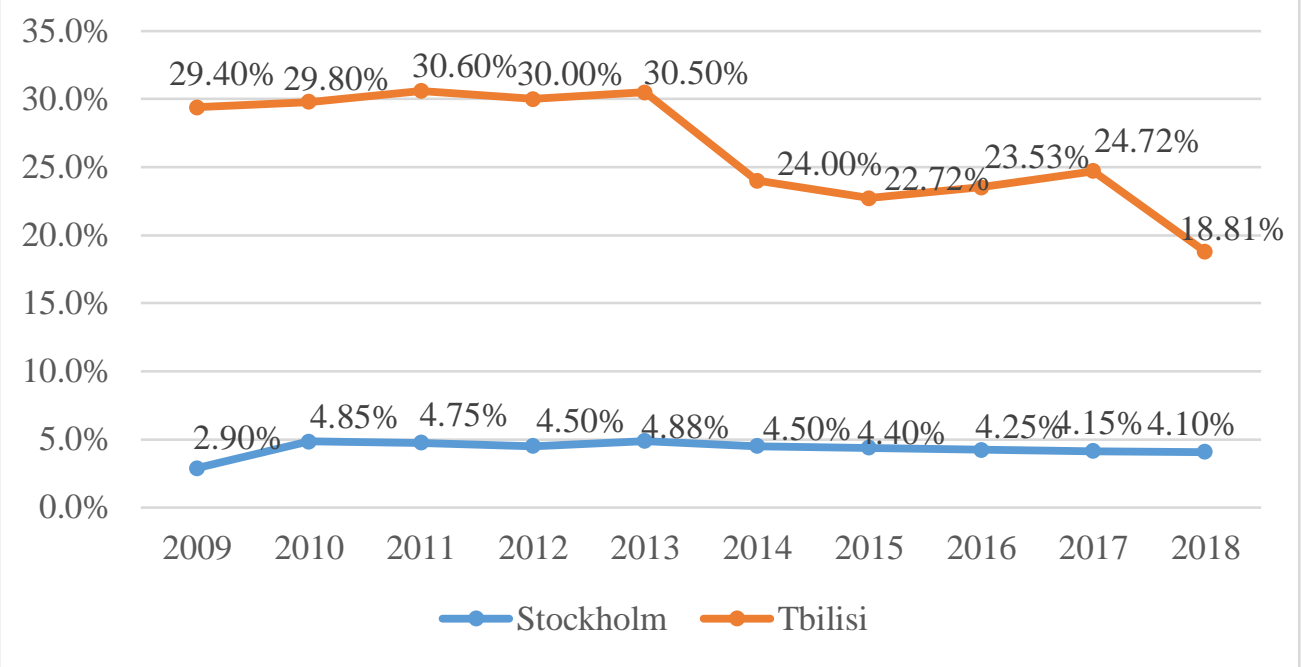

A comparative analysis of the data revealed that, in the last three years, the number of employed people in Stockholm increased by 9000, 7300, and 16300 (Stockholm Business Region, n.d.). The increase, however, is much less in Tbilisi: 2015 - 3234, 2016 - 16093 (reduction), and 2017 - 23558 (National Statistics Office of Georgia, n.d.). This means that Stockholm annually employs about 10000 people, while the same number for Tbilisi is only 3566 (Table 8).

Table 8: Growth of number of employed people in 2016-2018

\begin{tabular}{lll}
\hline & Stockholm & Tbilisi \\
\hline $\mathbf{2 0 1 6}$ & 9000 & 3234 \\
\hline $\mathbf{2 0 1 7}$ & 7300 & -16093 \\
\hline $\mathbf{2 0 1 8}$ & 16300 & 23558 \\
\hline Average growth of employed people & $\mathbf{1 0 ~ 8 6 7}$ & $\mathbf{3 5 6 6}$ \\
\hline
\end{tabular}

Salary has been cited as the fourth key business-related indicator in the study. In order to analyze the data, descriptive statistics were used. Nine (9) years statistics of Tbilisi and Stockholm have been collected and studied. Since it is one of the richest countries in the world, its capital - Stockholm allows itself to offer quite high salaries to the population. Average monthly salary in Stockholm is almost ten times more than in Tbilisi (Figure 4). 
Figure 4: Average monthly salary in Stockholm and Tbilisi (in USD), 2010-2018

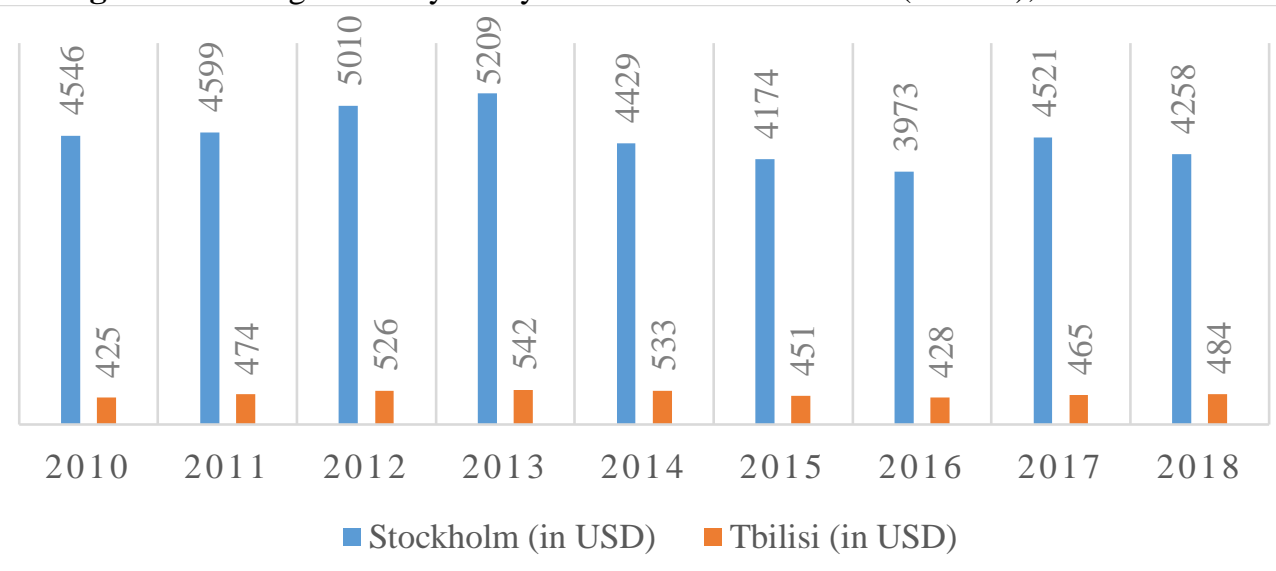

Unlike GDP, to accurately assess the indicators in relation to two cities of absolutely different economies, the growth rates have been computed. The study showed that the growth rate of average monthly salary in Stockholm ranges from $1.95 \%$ to $3.29 \%$ (Statistics Sweden, n.d.). For Tbilisi, the investigation revealed higher growth rate ranging from $5.05 \%$ to $10.18 \%$ (Table 9).

Table 9: Growth rate of average monthly salary in Stockholm and Tbilisi, 2010-2018

\begin{tabular}{lllll}
\hline & Stockholm (in SEK) & Growth rate & Tbilisi (in GEL) & Growth rate \\
\hline $\mathbf{2 0 1 0}$ & 30925 & & 752,996 & \\
\hline $\mathbf{2 0 1 1}$ & 31675 & $\mathbf{2 , 4 3 \%}$ & 791,013 & $\mathbf{5 , 0 5 \%}$ \\
\hline $\mathbf{2 0 1 2}$ & 32575 & $\mathbf{2 , 8 4 \%}$ & 871,548 & $\mathbf{1 0 , 1 8 \%}$ \\
\hline $\mathbf{2 0 1 3}$ & 33475 & $\mathbf{2 , 7 6 \%}$ & 942,792 & $\mathbf{8 , 1 7 \%}$ \\
\hline $\mathbf{2 0 1 4}$ & 34575 & $\mathbf{3 , 2 9 \%}$ & 997,178 & $\mathbf{5 , 7 7 \%}$ \\
\hline $\mathbf{2 0 1 5}$ & 35250 & $\mathbf{1 , 9 5 \%}$ & 1077,54 & $\mathbf{8 , 0 6 \%}$ \\
\hline $\mathbf{2 0 1 6}$ & 36150 & $\mathbf{2 , 5 5 \%}$ & 1135,06 & $\mathbf{5 , 3 4 \%}$ \\
\hline $\mathbf{2 0 1 7}$ & 37000 & $\mathbf{2 , 3 5 \%}$ & 1209,39 & $\mathbf{6 , 5 5 \%}$ \\
\hline $\mathbf{2 0 1 8}$ & 38050 & $\mathbf{2 , 8 4 \%}$ & 1286,36 & $\mathbf{6 , 3 6 \%}$ \\
\hline
\end{tabular}

The last identified key indicator that plays a crucial role in the development of business climate is foreign direct investments (FDI). For developing countries, FDIs represent one of the main sources for development since each investment brings huge contribution to the economy of the country. During the study, it was discovered that there is no statistical data available for the city of Stockholm in the online platforms, separately from the statistics of the country. Hence, the comparative analysis is carried out for Sweden and Georgia. This fact does not significantly damage the research process as the interest is more directed to the percentage of growth rather than the numbers. The study revealed that FDIs in Sweden are increasing steadily (Business Sweden, 2019) by $7 \%, 5 \%$, and $2 \%$ (Table 10). On the other hand, Georgia is 
facing unstable variations. This was witnessed in 2014 (National Statistics Office of Georgia, n.d.) when FDIs increased by $77 \%$, followed by $6 \%$ decrease in 2015, and 5\% decrease in 2016. The unsteady situation also continued in 2017 when FDIs recorded 19\% growth rate. Also, in 2018, Georgia experienced significant reduction in FDIs (36\%) since this fact is related to the global fall of cross-border direct investments in Europe. European magazines stated that this fact is caused by U.S. companies' massive repatriation of accumulated profits abroad (Business Sweden, 2019) which halved FDIs in many countries.

Table 10: FDIs in Sweden, Georgia, and Tbilisi and annual growth rates of FDIs

\begin{tabular}{lllllll}
\hline & $\mathbf{2 0 1 3}$ & $\mathbf{2 0 1 4}$ & $\mathbf{2 0 1 5}$ & $\mathbf{2 0 1 6}$ & $\mathbf{2 0 1 7}$ & $\mathbf{2 0 1 8}$ \\
\hline Sweden, SEK, Billion & 2545 & 2504 & 2679 & 2874 & 3018 & 3079 \\
\hline Growth rate, \% & & $-2 \%$ & $7 \%$ & $7 \%$ & $5 \%$ & $2 \%$ \\
\hline
\end{tabular}

\begin{tabular}{lllllll}
\hline Georgia, USD, mln & $\mathbf{1 0 3 9 , 2 0}$ & $\mathbf{1 ~ 8 3 7 , 0 0}$ & $\mathbf{1 7 2 9 , 1 0}$ & $\mathbf{1 6 5 0 , 3 0}$ & $\mathbf{1 9 6 2 , 6 0}$ & $\mathbf{1 2 6 5 , 2 0}$ \\
\hline Growth rate, \% & & $77 \%$ & $-6 \%$ & $-5 \%$ & $19 \%$ & $-36 \%$ \\
\hline & & & & & \\
\hline Tbilisi, USD, mln & $\mathbf{7 5 0 , 3}$ & $\mathbf{1 3 4 3 , 2}$ & $\mathbf{1 3 8 3 , 3}$ & $\mathbf{1 4 1 5 , 4}$ & $\mathbf{1 5 1 4 , 7}$ & $\mathbf{1 0 3 3 , 3}$ \\
\hline Growth rate, \% & & $79 \%$ & $3 \%$ & $2 \%$ & $7 \%$ & $-32 \%$ \\
\hline
\end{tabular}

\section{Results}

Based on the methods of the study, the paper exposed five (5) key business related indicators: new businesses, gross domestic product, employment, salary, and foreign direct investments. The indicators were considered and analyzed for two cities - Tbilisi and Stockholm. To summarize the study for each indicator, the following results are highlighted:

New Businesses (target: Tbilisi must have the same percentage of increase in the number of newly registered businesses as Stockholm): According to the assessment framework, in order for Tbilisi to be anticipated as a truly smart city, the growth rate of the number of newly registered businesses must at least be equal to the percentage of Stockholm. In this indicator, having $11.63 \%$ growth rate, Tbilisi fully satisfies the criteria (Table 5). High average growth rate emphasizes the openness and ease of starting and registering businesses in the capital of Georgia. This fact is also proven by World Bank reports where Georgia holds $7^{\text {th }}$ place among 190 economies due to sophisticated regulations framework for doing business (World Bank Group, 2020).

Gross Domestic Product (target: Tbilisi must achieve the same average growth rate of GDP as Stockholm): Stockholm, as a truly Smart City, sets the minimum requirement that cities must meet for having an ambition of being declared as Smart. Table 3 indicates that Tbilisi must have at least the same average growth rate of GDP. The study made descriptive and 
comparative analysis of the data of both cities and it was revealed that Tbilisi satisfies the criteria (average growth rate of Tbilisi $-10.04 \%$; Stockholm $5.65 \%)$.

Employment (target: Tbilisi must increase the number of employed people with the same number annually as Stockholm does): As indicated in the assessment framework, Tbilisi must at least have the same number of annually employed people as Stockholm. The average number of annually employed people in Stockholm is 10867. Having the same criteria at the level of 3566, Tbilisi is still far away from meeting this goal.

Salary (target: Growth rate of average monthly salary of Tbilisi must equal (or be close to) its growth rate of GDP): While mentioning this indicator, the GDP of the country should also be taken into consideration. Table 3 sets target that the growth rate of average monthly salary of Tbilisi must equal (or should be close to) its growth rate of GDP. The latter is derived from the economic theories about wages (Altman, 2012; Kregel, 1972; Stirati, 1994; Ulfenborg \& Oltmans, 2017). According to these theories, there is a straightforward linkage between wages and economic growth. "The Theory of Wages in Classical Economics" (Stirati, 1994) points out Adam Smith's idea that the "dynamic equilibrium wage" should reflect the country's pace of economic growth. Antonella Stirati also underlines that coinciding growth rates of wages and economic growth determines equilibrium in economy and leads to increasing productivity.

Thus, Stockholm definitely showcases the equilibrium of $2.84 \%$ growth rate of average monthly salary ${ }^{10}$ and $5.97 \%$ growth rate of GDP in 2018. The study revealed that Tbilisi has never experienced a growth rate of average monthly salary which is close to the growth rate of GDP. A close look at the data of 2018 shows that the average monthly salary increased by $6.36 \%$, while GDP amounted to $10.24 \%$ growth. Consequently, Tbilisi still needs development to advance in this indicator.

Foreign Direct Investments (target: Tbilisi must achieve the same percentage of increase in FDIs as Stockholm): The study showed that FDIs in Tbilisi is not developing in a sustainable way. There are also big differences in growth rates. Noticeable fluctuations are visible since there are negative growth rates as well. The study concluded that Tbilisi still needs efforts to meet the requirement set in the assessment framework and achieve the same percentage of FDI growth as Stockholm does.

\footnotetext{
${ }^{10}$ There is an assumption that Stockholm has about the same percentage of average monthly salary growth due to the absence of City data in this direction.
} 


\section{Conclusion}

The study aimed to assess the key indicators that measure Tbilisi performance towards the achievement of the Smart City solutions, which is related only to business development. The primary objective of the paper was to identify these indicators, while the second stage of the study focused on comparative analysis of Tbilisi data and Stockholm data. After in-depth consideration of the enormous statistical materials, the study had to point out the areas where Tbilisi needs to strengthen its positions and implement quite a number of crucial initiatives.

The study revealed the following business-related indicators: new businesses, gross domestic product, employment, salary, and foreign direct investments. The City of Stockholm was selected for comparative analysis and to determine the goals to be achieved by Tbilisi from the viewpoint of business development.

Assessment framework was elaborated. The framework incorporated the method for assessing each indicator and minimum requirements were also set for Tbilisi to achieve good business performance.

Therefore, it can be concluded that, from business perspectives, in 3 out of the 5 indicators, Tbilisi still needs to improve performance (Table 11).

Table 11: Checklist of indicators

\begin{tabular}{lllll}
\hline $\begin{array}{l}\text { New } \\
\text { Businesses }\end{array}$ & $\begin{array}{l}\text { Gross } \\
\text { Domestic } \\
\text { Product }\end{array}$ & Employment & Salary & $\begin{array}{l}\text { Foreign Direct } \\
\text { Investments }\end{array}$ \\
\hline$\checkmark$ & $\checkmark$ & Not satisfied & Not satisfied & Not satisfied \\
\hline
\end{tabular}

To be considered as truly Smart, Tbilisi needs to have positive evaluation in all five indicators represented in the table above. Therefore, the capital city of Georgia needs to meet the requirements set in Table 3. In order to achieve this complicated and long-term objective, Tbilisi should elaborate local economic development strategy, introduce goal-oriented action plan, and initiate smart and sustainable project ideas.

\section{References:}

1. Ahvenniemi, H., Huovila, A., Pinto-Seppa, I., \& Airaksinen, M. (2016). What are the differences between sustainable and smart cities? Cities 60 (2017), 234-245. https://daneshyari.com/article/preview/6481282.pdf

2. Altman, M. (2012). Economic Growth and the High Wage Economy. Routledge.

3. Angelakoglou, K., Nikolopoulos, N., Giourka, P., Svensson, I., Tsarchopoulos, P., Tryferidis, A., \& Tzovaras, D. (2019). A Methodological Framework for the Selection of Key Performance 
Indicators to Assess Smart City Solutions. Smart Cities 2019. 2(2), 269-306. https://doi.org/10.3390/smartcities2020018

4. Barba-Sancez, V., Arias-Antunez, E., \& Orozco-Barbosa, L. (2019). Smart cities as a source for entrepreneurial opportunities: Evidence for Spain. https://doi.org/10.1016/j.techfore.2019.119713

5. Bee Smart City (n.d.). Smart City Indicators: Six Strategic Fields of Action. https://hub.beesmart.city/smart-city-indicators/

6. Berst, J. (2013). The secret to smart cities success: start with a roadmap. Smart Cities Council.

https://smartcitiescouncil.com/article/secret-smart-cities-successstart-roadmap

7. Bibri, S.E. (2017). A foundational framework for smart sustainable city development: Theoretical, disciplinary, and discursive dimensions and their synergies. Sustainable Cities and Society. https://doi.org/10.1016/j.scs.2017.12.032

8. Business Sweden (2019). FDI Overview 2019. Direct Investment in the Global and Swedish Economy. https://www.businesssweden.com/globalassets/insights/global-analysis/fdi/fdi-overview2019.pdf

9. Business Sweden (n.d.). Foreign Direct Investments 2019. https://www.business-sweden.com/insights/global-analysis/fdioverview/

10. Caragliu, A., Del Bo, C., \& Nijkamp, P. (2009). Smart cities in Europe. VU University Amsterdam, Faculty of Economics, Business Administration and Econometrics. https://intaaivn.org/images/cc/Urbanism/background\%20documents/01_03_Nij kamp.pdf

11. Dabeedooal, Y. J., Dindoyal, V., Allam, Z., \& Jones, D. J. (2019). Smart Tourism as a Pillar for Sustainable Urban Development: An Alternate Smart City Strategy from Mauritius. Smart Cities 2019. 2(2), 153-162. https://doi.org/10.3390/smartcities2020011

12. Dall'O, G., Bruni, E., Panza, A., Sarto, L., \& Khayatian, F. (2017). Evaluation of cities' smartness by means of indicators for small and medium cities and communities: A methodology for Northern Italy. Sustainable Cities and Society, 34, 193-202.

https://doi.org/10.1016/j.scs.2017.06.021

13. Department for Business, Innovation, and Skills (2013). Smart cities: background paper.

https://assets.publishing.service.gov.uk/government/uploads/system/u ploads/attachment_data/file/246019/bis-13-1209-smart-citiesbackground-paper-digital.pdf 
14. Ellsmoor, J. (2019). Smart Cities: The Future Of Urban Development. Forbes.

https://www.forbes.com/sites/jamesellsmoor/2019/05/19/smart-citiesthe-future-of-urban-development/\#1 e6a068b2f90

15. Forbes Georgia (2018). Tbilisi ranks 112th among "smart cities". https://forbes.ge/news/4396/Tbilisi-ranks-112-th-among-smart-cities

16. Georgia (2012). About Tbilisi - A Smart City. https://georgiaabout.com/2012/08/23/about-tbilisi-a-smart-city/

17. Giffinger, R. \& Gudrun, H. (2009). Smart cities ranking: An effective instrument for the positioning of the cities.

https://core.ac.uk/download/pdf/41793309.pdf

18. Giffnger, R., Fertner, C., Kramar, H., Kalasek, R., Pichler-Milanovic, N., \& Meijers, E. (2007). Smart Cities: Ranking of European MediumSized Cities; Centre of Regional Science (SRF), Vienna University of Technology. http://www.smart-cities.eu/download/smart_cities_final_report.pdf

19. Giourka, P., Sanders, M. W. J. L., Angelakoglou, K., Pramangioulis, D., Nikolopoulos, N., Rakopoulos, D., Tryferidis, A., \& Tzovaras, D. (2019). The Smart City Business Model Canvas -A Smart City Business Modeling Framework and Practical Tool. Energies 2019. 12(24), https://doi.org/10.3390/en12244798

20. Girardi, P. \& Temporelli, A. (2016). Smartainability: A methodology for assessing the sustainability of the smart city. Energy Procedia. 111 (2017), $810-816$.

http://iranarze.ir/wp-content/uploads/2018/04/E6584-IranArze.pdf

21. Government Europa (2019). Smart City of 2019: Stockholm is world's smartest city. https://www.governmenteuropa.eu/smart-city-of-2019stockholm/95554/

22. Gupta, K. \& Hall, R. P. (2020). Understanding the What, Why, and How of Becoming a Smart City: Experiences from Kakinada and Kanpur. Smart Cities 2020. 3(2), 232-247. https://doi.org/10.3390/smartcities3020014

23. Hajikhani, A. (2020). Impact of Entrepreneurial Ecosystem Discussions in Smart Cities: Comprehensive Assessment of Social Media Data. Smart Cities 2020. 3(1), 112-137. https://doi.org/10.3390/smartcities3010007

24. Hoornweg, D. (2011). Smart Cities for Dummies. World Bank Blogs. https://blogs.worldbank.org/sustainablecities/smart-cities-fordummies

25. Jobs Europe (2017). What are the average salaries in Sweden? https://jobseurope.net/2017/08/31/average-salaries-sweden/ 
26. Kregel, J. A. (1972). Theory of Economic Growth. The Macmillan Press.

27. Monzon, A. (2015). Smart Cities Concept and Challenges - Bases for the Assessment of Smart City Projects. Smart Cities, Green Technologies, and Intelligent Transport Systems. https://doi.org/10.1007/978-3-319-27753-0_2

28. Narmania, D. \& Shaburishvili, S. (2017). Smart City Management Examples of Tbilisi City. International collective monograph. Vol. 2. 139-146.

29. National Agency of Public Registry of Ministry of Justice of Georgia (n.d.). Business entities. https://napr.gov.ge/p/1500

30. National Statistics Office of Georgia (n.d.). Statistical data of Georgia. https://www.geostat.ge/en

31. Organization for Economic Cooperation and Development (2019). Regions and Cities at a Glance 2018 - Sweden.

https://www.oecd.org/cfe/SWEDEN-Regions-and-Cities-2018.pdf

32. Porter, M. (2008). On Competition. Harvard Business School Publishing.

33. Richter, C., Kraus, S., \& Syrja, P. (2015). The Smart City as an opportunity for entrepreneurship. International Journal of Entrepreneurial Venturing. 7(3), 211-226.

https://ideas.repec.org/a/ids/ijeven/v7y2015i3p211-226.html

34. Ritchie, H. \& Roser, M. (2019). Urbanization. Our World in Data. https://ourworldindata.org/urbanization\#what-share-of-people-willlive-in-urban-areas-in-the-future

35. Schwab, K. (2019). The Global Competitiveness Report 2019. World Economic Forum.

http://www3.weforum.org/docs/WEF_TheGlobalCompetitivenessRe port2019.pdf

36. Statista (2020). Average monthly salary in Sweden in 2016. https:/www.statista.com/statistics/740104/average-monthly-salaryin-sweden-by-county/

37. Statistics Sweden (n.d.). Statistical data of Sweden. https://www.scb.se/en/

38. Stirati, A. (1994). The Theory of Wages in Classical Economics: A Study of Adam Smith, David Ricardo and their Contemporaries. Edward Elgar Publishing Company.

39. Stockholm Business Region (n.d.). Facts and Figures. https://www.stockholmbusinessregion.com/

40. Tbilisi Municipality City Hall (n.d.). Tbilisi Local Economic Development Plan. 
http://tbilisi.gov.ge/img/original/2020/2/27/Tbilisi-Local-EconomicDevelopment-Plan.pdf

41. Ulfenborg, N. Z. \& Oltmans, I. H. (2017). CEO remuneration packages in Sweden and their relevance for shareholder wealth.

http://www.divaportal.org/smash/get/diva2:1106072/FULLTEXT01.pdf

42. United Nations, Department of Economic and Social Affairs, Population Division (2019). World Urbanization Prospects. The 2018 Revision. https://population.un.org/wup/Publications/Files/WUP2018Report.pdf

43. Vienna University of Technology (n.d.). The smart city model. Europeansmartcities http://smart-cities.eu/?cid=2\&ver=4

44. World Bank Group (2020). Doing Business 2020. Comparing Business Regulation in 190 Economies. Economy Profile Georgia https://www.doingbusiness.org/content/dam/doingBusiness/country/g /georgia/GEO.pdf

45. World Council on City Data (n.d.). Created by Cities for Cities. https://www.dataforcities.org/

46. World Economic Forum (2014). The Competitiveness of Cities: A report of the Global Agenda Council on Competitiveness. http://www3.weforum.org/docs/GAC/2014/WEF_GAC_Competitive nessOfCities_Report_2014.pdf

47. World Economic Forum (n.d.). Georgia. The Global Competitiveness Index 2017-2018 edition. http://www3.weforum.org/docs/GCR20172018/03CountryProfiles/Standalone2pagerprofiles/WEF_GCI_2017_2018_Profile_Georgia.pdf

48. World Economic Forum (n.d.). Global Competitiveness Report 2019: How to end a lost decade of productivity growth.

https://www.weforum.org/reports/how-to-end-a-decade-of-lostproductivity-growth

49. Wray, S. (2019). Stockholm is 2019's winner at Smart City Expo World Congress. SmartCities World. https://www.smartcitiesworld.net/news/news/stockholm-is-2019swinning-city-at-smart-city-expo-world-congress-4803 